attached in my paper to any case not fully corroborated, and out of scores of such cases received some half-dozen have been published, as is expressly stated in my paper, in order to elicit further information on account of their intrinsic interest.

As regards the liability to overlook failures, I have referred to this point both at the outset of my paper (p. 4) and elsewhere; further (on pp. 238 and 239), I state: "It must be borne in mind that (especially among amateur dowsers) one is more likely to hear of success than failure, and therefore an extensive and searching inquiry is necessary before any safe induction can

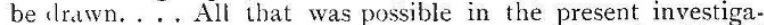
tion was to make the range of evidence as wide and unbiassed as possible, and not exclude a single case of failure that was substantiated. This has been done." It is, of course, easy to select, as your reviewer does, a certain number of cases in which the failures exceed the successes. ${ }^{1}$ But I think one is more likely to arrive at a correct estimate by the method I adopted, which was to make extensive inquiries, both generally and specifically, with regard to failures as well as successes in the case of every professional dowser I heard of. This is naturally a vastly more laborious method than your reviewer's, but was necessary in order to arrive at the actual facts in a subject which from all sides has been loosely discussed, albeit by eminent men, for upwards of 200 years.

I am glad to find your reviewer endorses certain cautions I suggested in the event of further investigation; though what he means by "thought-reading" as a source of crror is not quite clear. It is a matter of importance, more so than your reviewer appears to imagine, to recognise, and if possible exclude, the aid which the dowser derives from indications given by the surface of the ground. Long practice may give the most il literate person a power of detecting surface indications of underground water, or the faint tremor of unseen running water, that would entirely escape the ordinary observer, and of enabling correct inferences to be drawn even from indications that the dowser may have noticed quite unconsciously. We have here, doubtless, the explanation of some of the singular successes of dowsers in finding water; but a careful examination of the evidence I have collected has led me to think that no explanation hitherto suggested is adequate to account for all the facts. ${ }^{2}$

$$
\text { Kingstown, Co Dublin, October 2r, W. F. BARretT. }
$$

AT the head of Prof. Barrett's memoir is the following quotation from Mr. Andrew Lang: "There are two ways of investigating the facts or fancies about the divining rod. One is to examine it in its actual operation - a task of considerable labour, which will doubtless be undertaken by the Society for Psychical Research ; the other, and easier way, is to study the appearances of the divining wand in history." This naturally led me to think that Prof. Barrett intended to treat the subject as, in the main, a matter for personal investigation. He now claims, however, "to take the place of a judge in a court of inquiry." I therefore withdraw the term " hearsay" applied to the bulk of the evidence he has so laboriously collected, and will accept his own view of his position.

But Prof. Barrett will agree with me that this is a technical investigation needing expert knowledge. Now if so, where does the necessity for expert knowledge come in? Surely not after the experiments have all been malle, and the dowser is off the scene; but, as in any other scientific investigation, on the spot, with the man and the conditions all before you. This is the very core of the investigation, and no amount of after analysis can atone for the lack of personal observation and judgment exercised at this, the crucial point. But here, where expert knowledge and observation are essential, he relies on others, of whom the majority have no previous knowledge or scientific training whatever.

Prof. Barrett "had to exclude all evidence but that of eye. witnesses." As to his "I 52 numbered cases," 9 are avowedly supplied by people who, on their own statement, do not appear to be eye-witnesses. In $4 \mathrm{I}$ more there is nothing to show whether

1 The reviewer is, however, delightfully free from the pedantry of those who think accuracy desirable when dealing with such a contemptible superstition as the so-called divining-rod. 'This, I think, is apparent already; it becomes mure so when spec fic assertions of his are examined, such e.g. as "only two successes are $m=n t i o n e d$ in the Isle of Wight," \&c.

2 That a $\mathrm{m}$ xture of crass ignorance and charlat anry is to be found in many professional dowsers, crass ignorance and charlat anry is to be found in many prufessional dowsers, and that some of them are littie better than rogues. 1 only what might be expected; but, on the other hand, we have the fact that ro distinguished a sarant as M. Mortillet was once, as he tells us himself, a Presiont of he Ro an published a book on water-fluding in 1849. The President of the Royal Geological Suciety of Cornwall is still a successful

NO. I 46 ; , VOL. 57$]$ his informant met the dowser himself, or is trusting to information received from others. The information in 8 of these comes from a firm or joint-stock company; 8 are merely newspaper reports; some are ancient cases, which cannot now be inquired into.

With reference to the statement regarding liability to overlook failures, I did not state or wish to imply that Prof. Barrett had not fairly given all the failures which came to his knowledge. What I did wish to imply was, that his method of writing to the parties concerned for evidence on this point was not likely to yield much result.

As to the Isle of Wight, I may say, that not making it a habit to collect information regarding the employment of dowsers in different districts, I merely alluded to one where I happened to have stumbled upon facts bearing on the question. Whether or no other districts would give similar or contrary results I cannot say, having no material to go upon.

I fail to understand what meaning Prof. Barrett attaches to the term "surface indications." He agrees with me as to their great importance; yet there are only 32 cases in which his informants make even the slightest reference to this subject, and in only 8 is there any note that Prof. Barrett made special inquiries on this all-important point.

As previously stated, my criticisms apply to the bulk of the evidence. I thoroughly recognise the vilue of Prof. Barrett's personal observations, and have only to regret that these experiments form so very small a part of his memoir.

The Writer OF THE ARticle.

A Proposed Memorial to Prof. Victor Meyer.

THERE appears to be a strong desire among many of the British students who worked under the late Prof. Victor Meyer, to give expression to the feelings of gratitude and admiration with which they remember him, hy raising some furm of memorial to be placed in the Heidelberg Lecture Theatre.

It has therefore been decided to call a general meeting of Prof. Meyer's British students, to be held in Manchester on Salurday, December I. at at $5 \mathrm{p.m}$. Prof. H. B. Dixon, F.R.S., has kindly placed the Organic Lecture Theatre of Owens College at our disposal.

All past students of the late Victor Meyer. whether they worked with hin in Zürich, Göttingen or Heidelberg, are earnestly requested to be present.

I shall be pleased to receive suggestions from any who may be unable to attend, in order that they may be laid before the meeting.

University College, Nottingham, November 23

The Critical Temperature of Water.

CAN any of your readers tell me what is the critical temperature of water. I find in the supplement to Jamin and Bouty's "Cours de Physique" the critical temperature given as $370^{\circ} \mathrm{C}$. and the corresponding pressure as $195^{\circ} 5$ atmospheres. On the other hand, Cagniard-Latour gave this temperature as equal to the melting point of zinc, which is known to be about $415^{\circ} \mathrm{C}$.

I have some theoretical grounds for believing this latter figure to be the more accurate, so should be glad to know what other determinations, if any, have been made. II. M. Martin.

39 Guildford Stret, W.C., November 19.

\section{Coccoliths in our Coastal Waters}

IN our communication to NATURE, September I6, I897, we say "the presence of these bodies (coccoliths) in our coastal waters does not appear to have been recorded." Since this was written we find that Dr. Wallich, in the Ann. and Mag. of Natural Hist., vol. ii. I868. p. 319, stated "Coccospheres have been met with by me profusely . . . in material collected at the surface of the open seas of the tropics, and also in dredgings from shoal water off the south coast of England"

November 18 .

HENRY H Dixon.

\section{Phenomena Exhibited by Jackson Tubes.}

WHILE investigating the best methods of working the ordinary form of Jackson tubes during the last fourtcen months, I have noted the following interesting phenomena.

Four tubes developed a phosphorescent ring or halo rotating rapidly round the anode, which ly carefully heating became comparatively steady; this I ventured $t$, name the Saturn condition. 